\title{
Association Between Job Satisfactions upon the Dimensions of Organizational Citizenship Behaviour: Evidence from Administrative Staff of State Universities in Sri Lanka
}

\author{
M G G Hemakumara,Ph,D. \\ Senior Lecturer, Institute of Human Resource Advancement, University of Colombo, Sri Lanka
}

\begin{abstract}
Research on job satisfaction has focused on the effect of job satisfaction on organizational citizenship behaviour $(\mathrm{OCB})$ in general. This study explore the association between job satisfaction and dimensions of OCB based on the administrative staff of Sri Lankan state universities in Sri Lanka. The focus of this study was to analyze the effect of job satisfaction on dimensions of organizational citizenship behaviour of administrative staff of 15 state universities in Sri Lanka. Established questionnaires were used to collect data. A total of 168 questionnaires were used for the analysis. The data was analyzed by SPSS package.. it can be concluded that that job satisfaction predict all the five dimensions of OCB such as altruism, conscientiousness, sportsmanship, courtesy and civic virtue.

Keywords: altruism, conscientiousness, courtesy, job satisfaction, organizational citizenship behavior, sportsmanship
\end{abstract}

DOI: $10.7176 / \mathrm{EJBM} / 13-3-03$

Publication date: January $31^{\text {st }} 2021$

\section{Introduction}

The word satisfaction has come to English Language from Latin words of satis and facio which means good and act of doing respectively (Yonus and Ishak,2012). The concept of job satisfaction is a popular topic in the field of management research today. Employee job satisfaction is a topic which has received attention from both academia and business practitioners. (Hanaysha,2016).

Job satisfaction is essential for determining organization citizenship behavior (OCB). Employees have a high level of OCB will help the organization to achieve its objectives and contribute to organizations effectiveness and performance (Organ 2018). Job satisfaction is important not only to satisfy employees but to improve OCB.. Previous studies had revealed the strong relationship between job satisfaction and OCB. Further, these studies have explored the highly satisfied employees show high OCB than others. (Organ 2018; Unal 2013, Pavalachellie 2013, Arif \& Chohan 2012; Maio \& Kim 2010).

However the most of studies have explored the general relationship between job satisfactions and OCB. In such scenario this study aims to explore the association between job satisfactions upon the five dimensions of OCB separately, based on the evidence from administrative staff of state universities in Sri Lanka.

\section{Literature Review}

\subsection{Job Satisfaction}

The concept of job satisfaction has been introduced by Hoppock in 1935 (Tai and Chuang, 2014). Today job satisfaction is a topic of the most commonly used in organizational behavior. Job satisfaction is defined as the level which an individual like or dislike his or her job. Therefore, job satisfaction is a reaction which employees hold on their jobs. Irrespective of the size of the organization, the job dissatisfaction may seriously affect. Employees those with low or less job satisfaction may suffer from a high level of job stress. Negative attitude of one dissatisfied employee may spread throughout the organization causing declining moral (Motevalli andChevalier 2015).

Moradi et al. (2012) proposed that the job satisfaction is an individual emotional state which is resulting from his or her appraisal of job and attitude towards it..Nayantika et al. (2015) defined job satisfaction as an indicator which measure of how well an employee is performing his or her job.

\subsection{Organizational Citizenship Behaviour}

OCB is a modern management concept that has originated nearly thirty years ago. Many scholars have explored that OCB has an essential impact on organizations effectiveness in increasing employee morale and fulfilling organizations objectives (Demirel et al. 2018). OCB is an individual behavior which could motivate employees to go beyond the expected work level by the organization and their job description. This behavior benefits both employees and the individual (Mohamed ,2016). According to Zeyda (2018), OCB is optional and voluntary behavior that an individual would play and these behaviours are not aiming to satisfy or fulfill employees own personal benefit but to encourage engagement in the organization. However, OCB is of great importance to both the organization and the employee. Unal (2013) has explored the five dimensions of OCB as altruism, 
conscientiousness, sportsmanship, courtesy and civic virtue. Altruism is the helpfulness or helping behavior. Conscientiousness is a discretionary behavior which goes even beyond the minimum duty requirement of the organization. Sportsmanship is the willingness of tolerating personal inconveniences and doing duty without complains protests, accusations or grievances. Courtesy is preventing creating problems among co-workers and reduce intergroup conflicts. Civic virtue is the employee's concern or involvement about the life of the organization, monitor organizations opportunities and treats, look for the best interest of the organization and the willingness of active participation for organizations events

\section{The Sample Profile}

The study consists of 168 usable respondents. Out of which 69 ((41.1\%) are males while 99 (58.9\%) are females. The sample respondents represent four administrative positions in universities. That is registrars, deputy registrar, senior assistant registrar and assistant registrar. The present study sample represent $69(41.1 \%)$ assistant registrars, $68(40.5 \%)$ senior assistant registrars and $29(17.3 \%)$ deputy registrars.

The experience in the preset post also inquired. The, majority $100(59.5 \%)$ respondents having 1-5 years' experience, while there are only $2(1.2 \%)$ respondents having 21 or more years' experience. Secondary highest number of respondents, $33(19.6 \%)$ having 6-10 years' experience in the present post.

\section{Association Between Job Satisfaction Upon the Dimensions of Organizational Citizenship Behaviour}

The relationship between job satisfaction and five dimensions of OCB was tested separately. The results of the regression analysis of altruism, conscientiousness, sportsmanship, courtesy and civic virtue with Job Satisfaction is given in the following sections.

\subsection{The Regression of Altruism Upon Job Satisfaction}

The $\mathrm{P}$ value for the regression analysis is 0.003 which is less than 0.05 . Which means Job Satisfaction can be used to predict Altruism. The R-Square value is 0.052 which means $5 \%$ of the variation in Altruism can be explained by Job Satisfaction. The Durbin-Watson statistic is 1.892 which is not too for from 2 . Therefore there is no problem of autocorrelation. The $\mathrm{P}$ value Job Satisfaction is 0.03 which is less than 0.05 . Therefore Job Satisfaction is a significant predictor of Altruism.

According to the Table 1 the $95 \%$ confidence interval for Job Satisfaction is $(0.073,0.347)$ where the value of 0 does not fall within the interval, again indicating Job Satisfaction is a significant predator. The VIF value is below 5 , indicating that there is no problem of multicollienearity

Table1. The Regression of Altruism Upon Job Satisfaction

\begin{tabular}{|c|c|c|c|c|c|c|c|c|c|}
\hline \multirow[t]{2}{*}{ Variable } & \multicolumn{2}{|c|}{$\begin{array}{l}\text { Unstandardized } \\
\text { Coefficients }\end{array}$} & \multirow{2}{*}{$\begin{array}{c}\begin{array}{c}\text { Standardized } \\
\text { Coefficients }\end{array} \\
\text { Beta }\end{array}$} & \multirow[t]{2}{*}{$\mathbf{t}$} & \multirow[t]{2}{*}{$\begin{array}{c}\mathbf{P} \\
\text { value }\end{array}$} & \multicolumn{2}{|c|}{$\begin{array}{l}\text { 95.0\% Confidence } \\
\text { Interval for B }\end{array}$} & \multicolumn{2}{|c|}{$\begin{array}{l}\text { Collinearity } \\
\text { Statistics }\end{array}$} \\
\hline & B & $\begin{array}{l}\text { Std. } \\
\text { Error }\end{array}$ & & & & $\begin{array}{l}\text { Lower } \\
\text { Bound }\end{array}$ & $\begin{array}{l}\text { Upper } \\
\text { Bound }\end{array}$ & Tolerance & VIF \\
\hline$\overline{\text { (Cons }}$ & 3.363 & .254 & & 13.232 & .000 & 2.861 & 3.864 & & \\
\hline Job Satisfaction & .210 & 069 & .229 & 3.026 & .003 & .073 & .347 & 1.000 & 1.000 \\
\hline
\end{tabular}

\subsection{The Regression of Conscientiousness Upon Job Satisfaction}

The $\mathrm{P}$ value for the regression analysis is 0.011 which is less than 0.05 . Which means Job Satisfaction can be used to predict Conscientiousness. The R-Square value is 0.038 which means $4 \%$ of the variation in Conscientiousness can be explained by Job Satisfaction. The Durbin-Watson statistic is 2.007 which is not too for from 2 . Therefore there is no problem of autocorrelation. The $\mathrm{P}$ value Job Satisfaction is 0.011 which is less than 0.05 . Therefore Job Satisfaction is a significant predictor of Conscientiousness.

According to the Table 2 the 95\% confidence interval for Job Satisfaction is $(0.052,0.399)$ where the value of 0 does not fall within the interval, again indicating Job Satisfaction is a significant predator. The VIF value is below 5 , indicating that there is no problem of multicollienearity

Table 2.The Regression of Conscientiousness Upon Job Satisfaction

\begin{tabular}{|c|c|c|c|c|c|c|c|c|c|}
\hline \multirow[t]{2}{*}{ Variable } & \multicolumn{2}{|c|}{$\begin{array}{c}\text { Unstandardized } \\
\text { Coefficients }\end{array}$} & \multirow{2}{*}{$\begin{array}{c}\begin{array}{c}\text { Standardized } \\
\text { Coefficients }\end{array} \\
\text { Beta }\end{array}$} & \multirow[t]{2}{*}{$\mathbf{t}$} & \multirow[t]{2}{*}{$\begin{array}{c}\mathbf{P} \\
\text { value }\end{array}$} & \multicolumn{2}{|c|}{$\begin{array}{c}95.0 \% \text { Confidence } \\
\text { Interval for B } \\
\end{array}$} & \multicolumn{2}{|c|}{$\begin{array}{c}\text { Collinearity } \\
\text { Statistics } \\
\end{array}$} \\
\hline & B & $\begin{array}{l}\text { Std. } \\
\text { Error }\end{array}$ & & & & $\begin{array}{l}\text { Lower } \\
\text { Bound }\end{array}$ & $\begin{array}{l}\text { Upper } \\
\text { Bound }\end{array}$ & Tolerance & VIF \\
\hline Con & 3.280 & .321 & & 10.205 & .000 & 2.646 & 3.915 & & \\
\hline Job Satisfaction & .225 & 088 & .195 & 2.564 & .011 & .052 & .399 & 1.000 & 1.000 \\
\hline
\end{tabular}

4..3 The Regression of Sportsmanship Upon Job Satisfaction

The $\mathrm{P}$ value for the regression analysis is 0.000 which is less than 0.05 . Which means job Satisfaction can be used 
to predict Sportsmanship. The R-Square value is 0.100 which means $10 \%$ of the variation in Sportsmanship can be explained by Job Satisfaction. The Durbin-Watson statistic is 2.069 which is not too for from 2 . Therefore there is no problem of autocorrelation. The P value Job Satisfaction is 0.00 which is less than 0.05 . Therefore Job Satisfaction is a significant predictor of Sportsmanship.

According to the Table 3 the $95 \%$ confidence interval for Job Satisfaction is $(0.168,0.456)$ where the value of 0 does not fall within the interval, again indicating Job Satisfaction is a significant predator. The VIF value is below 5, indicating that there is no problem of multicollienearity

Table 3.The Regression of Sportsmanship Upon Job Satisfaction

\begin{tabular}{|c|c|c|c|c|c|c|c|c|c|}
\hline \multirow[t]{2}{*}{ Variable } & \multicolumn{2}{|c|}{$\begin{array}{l}\text { Unstandardized } \\
\text { Coefficients }\end{array}$} & \multirow{2}{*}{$\begin{array}{c}\begin{array}{c}\text { Standardized } \\
\text { Coefficients }\end{array} \\
\text { Beta }\end{array}$} & \multirow[t]{2}{*}{$\mathbf{t}$} & \multirow[t]{2}{*}{$\begin{array}{c}P \\
\text { value }\end{array}$} & \multicolumn{2}{|c|}{$\begin{array}{l}95.0 \% \text { Confidence } \\
\text { Interval for B }\end{array}$} & \multicolumn{2}{|c|}{$\begin{array}{l}\text { Collinearity } \\
\text { Statistics }\end{array}$} \\
\hline & B & $\begin{array}{l}\text { Std. } \\
\text { Error }\end{array}$ & & & & $\begin{array}{l}\text { Lower } \\
\text { Bound }\end{array}$ & $\begin{array}{l}\text { Upper } \\
\text { Bound }\end{array}$ & Tolerance & VIF \\
\hline Cons & 2.742 & .266 & & 10.297 & .000 & 2.216 & 3.268 & & \\
\hline Job Satisfaction & .312 & 073 & .316 & 4.285 & .003 & .168 & .456 & 1.000 & 1.000 \\
\hline
\end{tabular}

\subsection{The Regression of Courtesy upon Job Satisfaction}

The $\mathrm{P}$ value for the regression analysis is 0.000 which is less than 0.05 . Which means Job Satisfaction can be used to predict Courtesy. The R-Square value is 0.124 which means $12 \%$ of the variation in Courtesy can be explained by Job Satisfaction. The Durbin-Watson statistic is 2.162 which is not too for from 2 . Therefore there is no problem of autocorrelation. The $\mathrm{P}$ value Job Satisfaction is 0.00 which is less than 0.05 . Therefore Job Satisfaction is a significant predictor of Courtesy.

According to the Table 4, the 95\% confidence interval for Job Satisfaction is $(0.180,0.428)$ where the value of 0 does not fall within the interval, again indicating Job Satisfaction is a significant predator. The VIF value is below 5 , indicating that there is no problem of multicollienearity

Table 4. The Regression of Courtesy Upon Job Satisfaction

\begin{tabular}{|c|c|c|c|c|c|c|c|c|c|}
\hline \multirow[t]{2}{*}{ Variable } & \multicolumn{2}{|c|}{$\begin{array}{c}\text { Unstandardized } \\
\text { Coefficients } \\
\end{array}$} & \multirow{2}{*}{$\begin{array}{c}\begin{array}{c}\text { Standardized } \\
\text { Coefficients }\end{array} \\
\text { Beta }\end{array}$} & \multirow[t]{2}{*}{$\mathbf{t}$} & \multirow[t]{2}{*}{$\begin{array}{c}\mathbf{P} \\
\text { value }\end{array}$} & \multicolumn{2}{|c|}{$\begin{array}{l}95.0 \% \text { Confidence } \\
\text { Interval for B }\end{array}$} & \multicolumn{2}{|c|}{$\begin{array}{c}\text { Collinearity } \\
\text { Statistics }\end{array}$} \\
\hline & B & $\begin{array}{l}\text { Std. } \\
\text { Error }\end{array}$ & & & & $\begin{array}{l}\text { Lower } \\
\text { Bound }\end{array}$ & $\begin{array}{l}\text { Upper } \\
\text { Bound }\end{array}$ & Tolerance & VIF \\
\hline (Col & 2.990 & .229 & & 13.044 & .000 & 2.538 & 3.443 & & \\
\hline Job Satisfaction & .304 & 063 & .353 & 4.854 & .000 & .180 & .428 & 1.000 & 1.000 \\
\hline
\end{tabular}

\section{4..5. The Regression of Civic Virtue Upon Job Satisfaction}

The $\mathrm{P}$ value for the regression analysis is 0.000 which is less than 0.05 . Which means Job Satisfaction can be used to predict Civic Virtue. The R-Square value is 0.099 which means $10 \%$ of the variation in Civic Virtue can be explained by Job Satisfaction. The Durbin-Watson statistic is 1.734 which is not too for from 2 . Therefore there is no problem of autocorrelation. The $\mathrm{P}$ value Job Satisfaction is 0.000 which is less than 0.05 . Therefore Job Satisfaction is a significant predictor of Civic Virtue.

According to the Table 5 the $95 \%$ confidence interval for Job Satisfaction is $(0.182,0.531)$ where the value of 0 does not fall within the interval, again indicating Job Satisfaction is a significant predator. The VIF value is below 5 , indicating that there is no problem of multicollienearity

Table 5.The Regression of Civic Virtue Upon Job Satisfaction

\begin{tabular}{|c|c|c|c|c|c|c|c|c|c|}
\hline \multirow[t]{2}{*}{ Variable } & \multicolumn{2}{|c|}{$\begin{array}{l}\text { Unstandardized } \\
\text { Coefficients }\end{array}$} & \multirow{2}{*}{$\begin{array}{c}\begin{array}{c}\text { Standardized } \\
\text { Coefficients }\end{array} \\
\text { Beta }\end{array}$} & \multirow[t]{2}{*}{$\mathbf{t}$} & \multirow[t]{2}{*}{$\begin{array}{c}P \\
\text { value }\end{array}$} & \multicolumn{2}{|c|}{$\begin{array}{l}95.0 \% \text { Confidence } \\
\text { Interval for } B\end{array}$} & \multicolumn{2}{|c|}{$\begin{array}{c}\text { Collinearity } \\
\text { Statistics }\end{array}$} \\
\hline & B & $\begin{array}{c}\text { Std. } \\
\text { Error }\end{array}$ & & & & $\begin{array}{l}\text { Lower } \\
\text { Bound }\end{array}$ & $\begin{array}{l}\text { Upper } \\
\text { Bound }\end{array}$ & Tolerance & VIF \\
\hline Con & 2.511 & .324 & & 7.751 & .000 & 1.871 & 3.151 & & \\
\hline Job Satisfaction & .356 & 089 & .298 & 4.025 & .000 & .182 & .531 & 1.000 & 1.000 \\
\hline
\end{tabular}

\section{Conclusion}

The findings based on the study confirmed that job satisfaction predict all the five variables of OCB such as altruism, concientioness, sportsmanship, courtesy and civic virtue. All the five regression analysis has proven this relationship in an acceptable way. More or less the same conclusion has already being made by Basirudin et al (2016). Therefore the organizations those want to obtained the advantages of OCB must maintain the job satisfaction among employees.

\section{References}

Arif, A., \& Chohan, A. (2012). How job Satisfaction is influencing the organizational citizenship behavior (OCB): 
A study on employees working in banking sector of Pakistan. Interdisciplinary Journal of Contemporary Research in Business, 4(8), 74-88.

Basirudin, N. B., Basiruddin, R., Mokhber, M., Rasid, S. Z. A., \& Zamil, N. A. M. (2016). Organizational Citizenship Behaviour in Public Sector: Does Job Satisfaction Play a Role. International Journal of Economics and Financial Issues, 6, 376-381.

Demirel, Y., Elhusadi, I., \& Alhasadi, A. (2018). The Relationship between Organizational Citizenship Behavior and Organizational Factors. International Journal of Business and Management Invention (IJBMI), 7(3), $27-$ 39

Hanaysha, J. (2016). Determinants of Job Satisfaction in Higher Education Sector: Empirical Insights from Malaysia. International Journal of Human Resource Studies, 6, 129-146.

Miao, R., \& Kim, H.-G. (2010). Perceived organizational support, job satisfaction and employee performance: An Chinese empirical study. Journal of Service Science and Management

Mohamed, W. S. E. D. (2016). Investigating the Relationship between Job Satisfaction and Organizational Citizenship Behavior Among Beni Suef Cement Company Employees. 6(5), 2-7. viii.

Moradi, M., Honari, H., Naghshbandi, S., Jabari, N., \& Azarpira, G. (2012). The relationship between emotional intelligence and job satisfaction among coaches in premier under-20 football league.International Journal of Academic Research in Business and Social Sciences, 2(6), 73.

Motevalli, M., \& Chevalier, F. (2015). The effect of work motivation on job satisfaction: a case of farashian precast concrete company in iran. 4.

Nyantika, D. K., Kipchumba, S. K., Auka, D. O., \& Asienyo, B. O. (2015). Effect of Selected Motivational Factors on the Job Satisfaction of Civil Servants within Government Devolved Functions in Nakuru County. International Journal of Innovation and Applied Studies, 12(1), 287.

Organ, D. W. (2018). Organizational Citizenship Behavior: Recent Trends and Developments. Annual Review of Organizational Psychology and Organizational Behavior, 80, 295-306

Pavalache-Ilie, M. (2014). Organizational citizenship behaviour, work satisfaction and employees' personality. Procedia-Social and Behavioral Sciences, 127, 489-493.

Tai, F., M, \& Chuang, P. Y. (2014).Job Satisfaction of University Staff.The Journal of Human Resource and Adult Learning, 10, 51-64.

Ünal, A. P. Ö. F. (2013). Relationship between the facets of job satisfaction and the dimensions of organizational citizenship behavior: Mediating role of organizational commitment. Süleyman Demirel Üniversitesi İktisadi ve İdari Bilimler Fakültesi Dergisi, 18(1).

Yunus, N. K. Y., \& Ishak, S. (2012). The Relationship between Internal Satisfaction and External Satisfaction amongst Hotel Customers in Malaysia.International Journal of Economics Business and Management Studies, $1(1), 22-29$.

Zeyada, M. (2018).Organizational Culture and its Impact on Organizational Citizenship Behavior.International Journal of Academic Research in Business and Social Sciences, 8(3), 418-429. 